\title{
IMPACT OF DRY-OFF PERIOD BEFORE HARVEST AND POTASSIUM FERTILIZATION ON GROWTH, YIELD AND JUICE QUALITY OF SOME PROMISING SUGARCANE VARIETIES

\author{
Yasser M. Abdelazez
} \\ Sugar Crops Res. Inst., Agric. Res. Center, Giza, Egypt \\ Corresponding author: dr.yasserabdelazez@gmail.com
}

Key Words: Dry-off days, $\mathrm{K}_{2} \mathrm{O}$, soil, sugar cane varieties.

\section{ABSTRACT}

Afield trial including plant cane crop and $1^{\text {st }}$ ratoon were conducted in Mallawi Research Station-Minya Governorate (latitude of $28^{\circ} 10^{\prime} \mathrm{N}$, longitude of $30^{\circ} 75^{\prime} \mathrm{E}$ and altitude of $55 \mathrm{~m}$ above sea level) during $2017 / 2018$ and 2018/2019 seasons to study the effect of dry-off periods (30 and 45 days before harvesting date) and potassium fertilizer " $\mathrm{K}$ " levels (zero, 36 and $72 \mathrm{~kg} \mathrm{~K}$ O/fed) on yield and quality of the some sugarcane varieties (G.2003-47, G.2003-49, G.84-47 and G.2004-27), as compared with the commercial variety GT54-9. A split split-plot design with three replications was used. Drying-off periods were allocated in the main plots, whereas $\mathrm{K}$ levels were distributed in the sub-plot, and sugarcane varieties were randomly distributed in the sub-sub plot. The results showed that raising dry-off period from 30 to 45 days led to a significant decrease in cane yield reached $12 \%$ for the plant cane, corresponding to $10.92 \%$ in the $1^{\text {st }}$ ratoon. Increasing $\mathrm{K}$ level from zero up to $72 \mathrm{~kg} \mathrm{~K} 2 \mathrm{O} /$ fed produced an increase in sugar yield by $24.29 \%$ and $20.11 \%$ in the plant cane and the $1^{\text {st }}$ ratoon, respectively. Sugar yield was negatively affected by the increase of dry off days, which decreased by $13.6 \%$ in plant cane and $5.5 \%$ for the $1^{\text {st }}$ ratoon. However, sugar yield increased by raising $\mathrm{K}$ level up to $72 \mathrm{~kg}$ $\mathrm{K}_{2} \mathrm{O} /$ fed by $34 \%$ and $30.34 \%$ in the plant cane and the $1^{\text {st }}$ ratoon ، respectively. Under the conditions of the current work, it could be recommended that irrigating dry-off 30 days before harvesting date with 72 $\mathrm{kg} \mathrm{K}_{2} \mathrm{O} /$ fed would attain the highest cane and sugar yields/fed.

\section{INTRODUCTION}

Sugar cane is one of those crops that are seriously affected in quality by lesser moisture although it doesn't show much in growth (Kakde, 1985). Water stress causes primarily stomatal closure, decrease assimilation and therefore growth. Although water stress induces negative growth, it is not always injurious. In certain cases, it improves the quality of the plant products especially when the yield is a chemical constituent (sugar, fiber etc). Since water stress favours the decomposition of starch and protein for the formation of certain chemical constituents (Ramulu, 1998). 
Drying-off is easily accomplished on deep soils of good moisture holding capacity simply by withholding irrigation water for some weeks prior to harvest. On shallow soils adequate dry-off to induce ripening induces serious problems as the leaf canopy may be excessively damaged or on in extreme cases, the whole plant may be killed (Blackburn, 1984). Drying-off is also necessary for the practical purpose of allowing the mobility of in-field harvesting machineries. Soil wetness during harvest time has a pronounced effect on the mechanical properties of the soil (Daniel, 1982) and this has determining factor on the ease with which the crop will be harvested (efficiency, workability) and hence, has effect on successive ratoon management. Generally, ripening period is more important for its effect on juice quality and hence, optimum harvest time (Kakde, 1985). Irrigated sugarcane is dried off to prepare the field for harvesting and to increase sucrose yield (Singels et al, 2000). A gradual drying off irrigation holds much promise to increase yields and quality. In ratoon sugarcane, irrigation is often withheld before harvest to reduce soil compaction from harvesting machinery and to enhance quality parameters (brix \%, pol\%, purity and estimated recoverable) to be deposited preferentially in sugarcane stalks, (Inman-Bamber ,2004).

The ' $\mathrm{K}$ ' uptake varies with soil and ecological conditions, as it was low in Malawi (1.3 $\left.\mathrm{kg} \mathrm{t}^{-1} \mathrm{ha}^{-1}\right)$. The information available from different sets of soil and crop duration indicates different amount of ' $K$ ' utilized by the cane crop. Sugar cane is known as a potassium devourer, its need reaching 600 to $800 \mathrm{Kg} \mathrm{K}_{2} \mathrm{O}$ per hectare per harvest; since potassium influences important for most cell activities. It is a fact that today in most sugar cane areas, the cane crops uptake more potash from the soil, thus leaving negative potash balance, this observation shows that sugar cane areas are facing gradual potassium impoverishment (Husz, 1972). Potassium fertilization in Egyptian agriculture have become very important since the completion of the High Dam because of the deposition of the suspended Nile silt-rich in K bearing minerals in the upstream of the formed lake. So, the demand for potash fertilization has been increased (Abd El-Hadi, 1989 and Abd ElHadi et al., 1990), and may be because of the existence of dynamic equilibrium among the different sources of $\mathrm{K}$ in the soil. However, continuous crop removal without compensation is likely to cause an irreparable damage from the soil fertility of view. Potassium is an important nutrient in sugarcane development and acts as an enzyme activator in the plant metabolism such as in photosynthesis, protein synthesis and translocation of sucrose from leaves to the stalk storage tissues. Also, it is one of the essential elements required for growth and development of cane plant. El-Geddawy et al., (2015) found that potassium element was the highest common factor attained a significant effectiveness on cane and sugar yield and their attributes. Increasing the applied dose of potassium fertilizer 
was accompanied by a significant increase in the values of stalk length, stalk thickness and stalk weight/plant in both seasons. Brix and sucrose percentages, sugar recovery $\%$ and millable cane number were significantly and positively responded to the increasing in potassium levels up to $64 \mathrm{~kg}$ $\mathrm{K} 2 \mathrm{O} / \mathrm{fed}$, however, $32 \mathrm{~kg} \mathrm{~K} 2 \mathrm{O} / \mathrm{fed}$ was enough to recorded the highest significant values of purity in both seasons. Abu-Ellail et al., (2019) found that increasing potassium levels significantly increased stalk length, stalk diameter, stalk weight and number of stalk $/ \mathrm{m}^{2}$, millable cane and yields of cane and sugar. Potassium nutrition is very important for the ratoon crop and it has got significant role in improving the cane yield and juice quality. Potassium is the largest inorganic constituent of sugar juice amounting 34.50 per cent of the ash. It is also observed that higher content of potassium in the leaf sheath during the early growth phase (4 - 6 months) increase the yields and sugar content (Singh et al., 1999). Ahmed et al., (2013) studied all possible combinations of three planting parts (top, middle and bottom), three $\mathrm{K}$ application rates $\left(60\right.$ and $\left.90 \mathrm{~kg} / \mathrm{ha}^{-1}\right)$ and two varieties of sugarcane (NCS 008 and Bida local). They concluded that potassium application of $90 \mathrm{~kg} / \mathrm{ha}-$ ${ }^{1}$ is recommended for optimal growth and yield.

The objectives of this paper were to determine the impact of dryingoff on cane and sugar yields and its components, as well as to quantify the relationship between dry-off and potassium fertilization in sugarcane varsities.

\section{MATERIALS AND METHODS}

Field trials including plant cane crop (2017/2018 season) and $1^{\text {st }}$ ratoon (2018/2019 season) were conducted in Mallawi Agricultural Research Station, EL-Minia Governorate, Egypt (latitude of $28^{\circ} 10^{\prime} \mathrm{N}$, longitude of $30^{\circ} 75^{\prime} \mathrm{E}$ and altitude of $55 \mathrm{~m}$ above sea level), to investigate the effect of dry-off period before harvesting date (30 and 45 days) and potassium fertilizer rate ( 36 and $72 \mathrm{~kg} \mathrm{~K}_{2} \mathrm{O} / \mathrm{fed}$ ) on yield and juice quality of some sugarcane varieties viz, G.2003-47, G.2003-49, G.84-47, G.2004-27 and GT54-9. The experiment was laid out in a split split-plot design with three replications, withholding irrigation treatments were allocated in the main plots, while potassium fertilizer levels were distributed in the sub plot, and sugarcane varieties were randomly distributed in the sub-sub plot. Potassium fertilizer was applied as potassium sulphate $\left(48 \% \mathrm{~K}_{2} \mathrm{O}\right)$ in two doses after the $1^{\text {st }}$ and $2^{\text {nd }}$ hoeing, i.e. 45 and 75 days from planting. Soil chemical and mechanical analyses of the experimental site are presented in Table 1. The field was irrigated immediately right after planting and all agronomic and plant protection measures were kept uniform. The row length of $6 \mathrm{~m}$ and distance between rows was $1.0 \mathrm{~m}$, with plot area equal $18 \mathrm{~m}^{2}$. Planting was done during the $1^{\text {st }}$ of March 2017; plant crop was harvested on 12 months in the $1^{\text {st }}$ season and kept as a $1^{\text {st }}$ ratoon, in the $2^{\text {nd }}$ season. At harvest, data 
were recorded for the two crop years (planting; plant cane (PC) and $1^{\text {st }}$ ratoon (FR)). Thirty plants were randomly taken from each plot to study the following traits:

The recorded data

1. Stalk length $(\mathrm{cm})$

2. Stalk diameter $(\mathrm{cm})$

3. Cane yield (ton/fed) was calculated on the plot basis.

4. Brix percentage (total soluble solids, TSS \%) was determined using Brix Hydrometer, standardized at $20{ }^{\circ} \mathrm{C}$.

5. Sucrose percentage of clarified juice was determined by using Sacharemeter according to A.O.A.C. (1995).

6. Juice purity was calculated as: [(Sucrose / Brix ) x 100].

7. Sugar recovery\% was calculated according to the equation described by Yadav \& Sharma (1980) which is given below: $\mathrm{SR}=$ [Sucrose \% 0.4 (Brix - Sucrose \%)] x 0.73

where: $0.4=$ each pound of non-sucrose solids in the juice will retain 0.4 of a pound of sucrose and 0.73 is a correction factor for actual milling conditions in factories that depends on the overall mean cane fiber percentage during processing.

8. Sugar yield (ton/fed) was estimated by multiplying net cane yield (ton/fed) by sugar recovery percentage.

Table. 1. Soil chemical and mechanical analysis of the experimental site in both seasons.

\begin{tabular}{|l|c|c|}
\hline Seasons & $2017 / 2018$ & $2018 / 2019$ \\
\hline Coarse sand\% & Physical analysis \\
\hline Fine sand\% & 3 & 2.5 \\
\hline Silt\% & 14 & 13.5 \\
\hline Clay & 43 & 41.6 \\
\hline Soil texture & 40 & 42.4 \\
\hline \multicolumn{2}{|c|}{ Silty clay } & Silty clay \\
\hline So4 mg/g & 0.54 & 0.58 \\
\hline CaCo3\% & 2.11 & 1.94 \\
\hline E.C.(1:5 extract ) mmhos/cm & 1.82 & 1.71 \\
\hline PH(1:2.5 extract) & 7.84 & 7.91 \\
\hline Organic matter\% & 1.19 & 1.16 \\
\hline Available N (PPM) & 76.85 & 78.45 \\
\hline Available P (PPM) & 5.2 & 5.3 \\
\hline Available K (PPM) & 146 & 161 \\
\hline
\end{tabular}

Statistical Analysis:

Data were statistically analyzed using analysis of variance according to procedures outlined by Steel $\boldsymbol{e t}$ al., (1997) using MSTAT-C computer package by Freed $\boldsymbol{e t}$ al., (1989). Treatment mean comparisons were performed using the least significant difference (LSD) at 5\% level of probability. 


\section{RESULTS AND DISCUSSION Effect of drying-off and $K$ fertilizer on stalk length}

The results in table (2) showed that stalk length was significantly decreased with raising dry-off from 30 to 45 days from 247.00 to $237.93 \mathrm{~cm}$ in the plant cane and it was also decreased from 268.06 to $257.44 \mathrm{~cm}$ in plant cane and the $1^{\text {st }}$ ratoon. Meanwhile, stalk length was increased from 229.00 to $255.67 \mathrm{~cm}$ in $1^{\text {st }}$ and 247.97 to $275.28 \mathrm{~cm}$ in $2^{\text {nd }}$ season with increasing potassium fertilizer levels from zero to $72 \mathrm{~kg} \mathrm{~K}_{2} \mathrm{O} /$ fed. Gameh, et al., (2015) found that sugarcane stalk growth was positively responded to the $\mathrm{K}$ treatment. Data in same table cleared that the stalk length for sugar cane varieties was affected significantly in both seasons, the tallest plant was recorded by G.200347 variety $(269.50 \mathrm{~cm})$ in cane plant and $(286.17 \mathrm{~cm})$ in $1^{\text {st }}$ ratoon.

Table (2): Mean values of stalk length for sugarcane varieties as affected by dry-off days and potassium fertilization.

\begin{tabular}{|c|c|c|c|c|c|c|c|c|c|}
\hline \multirow{3}{*}{$\begin{array}{c}\text { Varieties } \\
(\mathbf{V})\end{array}$} & \multirow{3}{*}{$\begin{array}{l}\text { Dry-off } \\
\text { period } \\
\text { "day" } \\
\text { (D) }\end{array}$} & \multicolumn{8}{|c|}{ Potassium levels "kg $\mathrm{K}_{2} \mathrm{O} /$ fed" (K) } \\
\hline & & \multicolumn{4}{|c|}{$2017 / 2018$} & \multicolumn{4}{|c|}{ 2018/2019 } \\
\hline & & 0 & 36 & 72 & Mean & 0 & 36 & 72 & Mean \\
\hline \multirow{2}{*}{ G.2003-47 } & 88 & 259.66 & 280.00 & 293.66 & 277.77 & 276.00 & 296.00 & 308.00 & 293.33 \\
\hline & 45 & 250.33 & 264.33 & 269.00 & 261.22 & 261.66 & 281.00 & 294.33 & 279.00 \\
\hline \multicolumn{2}{|l|}{ Mean } & 255.00 & 272.17 & 281.33 & 269.50 & 268.83 & 288.50 & 301.17 & 286.17 \\
\hline \multirow{2}{*}{ G.2003-49 } & 30 & 229.00 & 239.66 & 252.66 & 240.44 & 258.66 & 273.00 & 284.33 & 272.00 \\
\hline & 45 & 221.00 & 231.33 & 241.00 & 231.11 & 251.33 & 265.66 & 271.45 & 267.11 \\
\hline \multicolumn{2}{|l|}{ Mean } & 225.00 & 235.50 & 246.83 & 235.78 & 255.00 & 269.33 & 277.89 & 269.55 \\
\hline \multirow{2}{*}{ G.84-47 } & 30 & 226.66 & 229.66 & 243.00 & 233.11 & 252.33 & 266.33 & 281.33 & 266.66 \\
\hline & 45 & 215.66 & 225.22 & 237.33 & 226.07 & 241.33 & 256.00 & 267.66 & 255.00 \\
\hline \multicolumn{2}{|l|}{ Mean } & 221.16 & 227.44 & 240.17 & 229.59 & 246.83 & 261.17 & 274.50 & 260.83 \\
\hline \multirow{2}{*}{ G.2004-27 } & 30 & 224.33 & 251.66 & 264.00 & 246.66 & 240.66 & 257.33 & 268.33 & 255.44 \\
\hline & 45 & 218.33 & 243.43 & 258.00 & 239.92 & 229.33 & 243.00 & 250.66 & 241.00 \\
\hline \multicolumn{2}{|l|}{ Mean } & 221.33 & 247.55 & 261.00 & 243.29 & 235.00 & 250.17 & 259.50 & 248.22 \\
\hline \multirow{2}{*}{ GT54-9 } & 30 & 225.00 & 233.66 & 252.33 & 237.00 & 237.00 & 252.33 & 269.33 & 252.89 \\
\hline & 45 & 220.00 & 228.33 & 245.66 & 231.33 & 231.33 & 246.66 & 257.33 & 245.11 \\
\hline \multicolumn{2}{|l|}{ Mean } & 222.50 & 231.00 & 249.00 & 234.16 & 234.17 & 249.50 & 263.33 & 249.00 \\
\hline \multirow{2}{*}{$\begin{array}{l}\text { Mean of } \\
\text { D x K }\end{array}$} & 30 & 232.93 & 246.93 & 261.13 & 247.00 & 252.93 & 269.00 & 282.26 & 268.06 \\
\hline & 45 & 225.06 & 238.53 & 250.20 & 237.93 & 243.00 & 258.46 & 268.29 & 257.44 \\
\hline \multicolumn{2}{|l|}{ Mean } & 229.00 & 242.73 & 255.67 & 242.46 & 247.97 & 263.73 & 275.28 & 262.75 \\
\hline \multicolumn{2}{|l|}{$\mathbf{V}$} & & & & 1.15 & & & & 1.33 \\
\hline \multicolumn{2}{|l|}{$\mathbf{K}$} & & & & 1.24 & & & & 1.63 \\
\hline \multicolumn{2}{|l|}{ D } & & & & 2.34 & & & & 2.30 \\
\hline \multicolumn{2}{|l|}{$V \times K$} & & & & NS & & & & NS \\
\hline \multicolumn{2}{|l|}{$\mathrm{V} \times \mathrm{D}$} & & & & 2.33 & & & & 3.76 \\
\hline \multicolumn{2}{|l|}{ K X D } & & & & NS & & & & 4.60 \\
\hline \multicolumn{2}{|l|}{ V $x K \times D$} & & & & NS & & & & NS \\
\hline
\end{tabular}

Data in Table (2) illustrated that the stalk length $(\mathrm{cm})$ was affected significantly by the interaction between all treatments in both seasons, except the $1^{\text {st }}$ order interaction between sugarcane varieties and $\mathrm{K}$ fertilizer treatments and the $2^{\text {nd }}$ interaction among the three studied factors. It was found that the increase in $\mathrm{K}$ fertilizer levels were increasable in stalk length $(\mathrm{cm})$, but it was decrease with raising of dry-off days with all experimental varieties in both 
seasons. The highest values at 30 dry-off days and $72 \mathrm{~kg} \mathrm{~K} / \mathrm{fed}$ by G.200347 variety were gave $(293.66 \mathrm{~cm})$ in plant cane and $(308.00 \mathrm{~cm})$ in the $1^{\text {st }}$ ratoon. Mahmoud et al., (2008) found that increasing potassium levels significantly increased stalk length, stalk diameter, stalk weight and number of stalk $/ \mathrm{m}^{2}$, millable cane and yields of cane and sugar. Differences among cane varieties in these traits were found by Abu-Ellail et al., (2019) and Masri et al., (2014).

\section{Effect of drying-off and $\mathbf{K}$ fertilizer on stalk diameter $(\mathbf{c m})$}

The results in Table (3) showed that increasing dry-off days and potassium levels were significantly affects on stalk diameter in both sugarcane crops. Stalk diameter was increased with raising potassium fertilizer levels. The results showed that adding $72 \mathrm{~kg} \mathrm{~K}_{2} \mathrm{O} /$ fed level had the highest value $(2.87 \mathrm{~cm})$ in plant cane and $(2.78 \mathrm{~cm})$ in the $1^{\text {st }}$ ratoon. Otherwise, stalk diameter was decreased with raising dry-off days from 30 to 45 days from $(2.73$ to $2.60 \mathrm{~cm})$ in plant cane, while it was decreased from $(2.63$ to $2.50 \mathrm{~cm})$ in the $1^{\text {st }}$ ratoon. Stalk diameter significantly varied between sugarcane varieties in both seasons. G.2003-49 variety registered the highest value $(2.75 \mathrm{~cm})$ in cane plant and its $1^{\text {st }}$ ratoon $(2.70 \mathrm{~cm})$. Azeredo and Peixota (1978) found that fertilization with $\mathrm{K}$ resulted in increasing stalk diameter and cane yield in the plant cane as well as first and second ratoons.

Table (3): Mean values of stalk diameter for sugarcane varieties as affected by dry-off days and potassium fertilization.

\begin{tabular}{|c|c|c|c|c|c|c|c|c|c|}
\hline \multirow{3}{*}{$\begin{array}{l}\text { Varieties } \\
\text { (V) }\end{array}$} & \multirow{3}{*}{$\begin{array}{l}\text { Dry-off period "day" } \\
\text { (D) }\end{array}$} & \multicolumn{8}{|c|}{ Potassium levels "kg K2O/fed" (K) } \\
\hline & & \multicolumn{4}{|c|}{$2017 / 2018$} & \multicolumn{4}{|c|}{$2018 / 2019$} \\
\hline & & $\mathbf{0}$ & 36 & 72 & Mean & $\mathbf{0}$ & 36 & 72 & Mean \\
\hline \multirow{2}{*}{ G.2003-47 } & 30 & 2.56 & 2.93 & 3.13 & 2.87 & 2.59 & 2.78 & 2.97 & 2.78 \\
\hline & 45 & 2.26 & 2.79 & 2.84 & 2.63 & 2.43 & 2.56 & 2.84 & 2.61 \\
\hline \multicolumn{2}{|l|}{ Mean } & 2.41 & 2.86 & 2.99 & 2.75 & 2.51 & 2.67 & 2.91 & 2.70 \\
\hline \multirow{2}{*}{ G.2003-49 } & 30 & 2.33 & 2.74 & 2.79 & 2.62 & 2.23 & 2.56 & 2.73 & 2.51 \\
\hline & 45 & 2.25 & 2.61 & 2.72 & 2.53 & 2.16 & 2.26 & 2.64 & 2.35 \\
\hline \multicolumn{2}{|l|}{ Mean } & 2.29 & 2.68 & 2.76 & 2.57 & 2.20 & 2.41 & 2.69 & 2.43 \\
\hline \multirow{2}{*}{ G.84-47 } & 30 & 2.33 & 2.75 & 2.86 & 2.65 & 2.43 & 2.61 & 2.86 & 2.63 \\
\hline & 45 & 2.25 & 2.66 & 2.71 & 2.54 & 2.37 & 2.51 & 2.66 & 2.51 \\
\hline \multicolumn{2}{|l|}{ Mean } & 2.29 & 2.71 & 2.79 & 2.59 & 2.40 & 2.56 & 2.76 & 2.57 \\
\hline \multirow{2}{*}{ G.2004-27 } & 30 & 2.46 & 2.88 & 3.01 & 2.78 & 2.53 & 2.67 & 2.83 & 2.68 \\
\hline & 45 & 2.39 & 2.64 & 2.85 & 2.63 & 2.38 & 2.54 & 2.94 & 2.62 \\
\hline \multicolumn{2}{|l|}{ Mean } & 2.43 & 2.76 & 2.93 & 2.71 & 2.46 & 2.61 & 2.89 & 2.65 \\
\hline \multirow{2}{*}{ GT54-9 } & 30 & 2.51 & 2.77 & 2.95 & 2.74 & 2.41 & 2.52 & 2.76 & 2.56 \\
\hline & 45 & 2.42 & 2.66 & 2.87 & 2.65 & 2.26 & 2.41 & 2.61 & 2.43 \\
\hline \multicolumn{2}{|l|}{ Mean } & 2.47 & 2.72 & 2.91 & 2.70 & 2.34 & 2.47 & 2.69 & 2.50 \\
\hline \multirow{2}{*}{$\begin{array}{l}\text { Mean of } \\
\text { D X K }\end{array}$} & 30 & 2.44 & 2.81 & 2.95 & 2.73 & 2.44 & 2.63 & 2.83 & 2.63 \\
\hline & 45 & 2.31 & 2.67 & 2.80 & 2.60 & 2.32 & 2.46 & 2.74 & 2.50 \\
\hline \multicolumn{2}{|l|}{ Mean } & 2.38 & 2.74 & 2.87 & 2.66 & 2.38 & 2.54 & 2.78 & 2.57 \\
\hline \multicolumn{2}{|l|}{$\mathbf{V}$} & & & & 0.15 & & & & 0.14 \\
\hline \multicolumn{2}{|l|}{$\mathbf{K}$} & & & & 0.26 & & & & 0.25 \\
\hline \multicolumn{2}{|l|}{ D } & & & & 0.14 & & & & 0.15 \\
\hline \multicolumn{2}{|l|}{$V \times K$} & & & & NS & & & & NS \\
\hline \multicolumn{2}{|l|}{ V x D } & & & & NS & & & & NS \\
\hline \multicolumn{2}{|l|}{ K x D } & & & & NS & & & & NS \\
\hline \multicolumn{2}{|l|}{ V $x K \times D$} & & & & NS & & & & NS \\
\hline
\end{tabular}


The interaction among the studied factors were not significant in stalk diameter in both seasons, Generally, it was found that the increase in $\mathrm{K}$ fertilizer levels were increasable stalk diameter $(\mathrm{cm})$, but it was decrease with raising of dry-off days with all experimental varieties in both seasons. The highest value at 30 dry-off days and $72 \mathrm{~kg} \mathrm{~K} / \mathrm{fed}$ by G.2003-47 variety gave $(3.13 \mathrm{~cm})$ in plant cane and $(2.97 \mathrm{~cm})$ for the $1^{\text {st }}$ ratoon.

\section{Effect of drying-off and $K$ fertilizer on cane yield}

Data in Table (4) cleared that cane yield varied significantly between sugar cane varieties, as well as between dry-off days and potassium levels in both seasons. Cane yield/fed was increased with raising potassium fertilizer levels. Adding $72 \mathrm{~kg} \mathrm{~K}_{2} \mathrm{O} / \mathrm{fed}$ had a maximum cane yield/fed (45.14 ton) in plant cane while in the first ratoon crop was (47.76 ton/fed). Meanwhile, with unfertilized treatment registered the lowest value of cane yield/fed (35.93 ton) in plant cane, while the lowest value reported with check treatment of $\mathrm{K}$ level (39.90 ton /fed) in the $1^{\text {st }}$ ratoon. Gameh et al., (2015) found that cane yield and its quality were increased by increasing potassium fertilization level. Cane yield was significantly influenced by drying off period, the reason could be reduction of plant height and stem diameter under extended drying off periods might have been offset by which greater accumulation of soluble solids (Hagos, 2014). The results indicated that the cane yield/fed decreased with raising dry-off days from 30 to 45 days from 42.76 to 38.39 ton/fed in cane plant, and from 46.18 to 41.88 ton/fed in the $1^{\text {st }}$ ratoon.

The results showed significant effect of the test varieties in both sugar cane crops. Data cleared that the highest value (42.55 and 47.98 ton/fed) was reported by G.2003-47 variety in plant cane and the $1^{\text {st }}$ ratoon, respectively. While the lowest value (38.60 ton/fed) was recorded with G.84-47 variety in plant cane and the $1^{\text {st }}$ ratoon (39.79 ton/fed) recorded by G.2004-27. Verma et al., (1998) reported that potassium application gave higher cane yield but had no effect on sugar content.

Data in Table (4) indicate that significant interaction between all treatments for cane yield (ton/fed.) in both seasons. The increase in $\mathrm{K}$ fertilizer levels was increasable in cane yield/fed, but it was decrease with raising dry-off days with all examined varieties in both seasons, except the $1^{\text {st }}$ order interaction between sugar cane varieties and potassium fertilizer and also between potassium fertilizer and dry-off days' treatments. The highest values were recorded at 30 dry-off days and $72 \mathrm{~kg} \mathrm{~K} 2 \mathrm{O} / \mathrm{fed}(49.90$ ton/fed.) in plant cane and (54.46 ton/fed.) in the $1^{\text {st }}$ ratoon with variety G.2003-47. Rossetto et al., (2004) evaluated the effect of potassium fertilization in the yield of ratoon sugarcane and observed significant increases with linear adjustments in six out of seven experiments, using the largest $\mathrm{K}$ fertilizer rate (200 kg ha- 1 of $\mathrm{K}_{2} \mathrm{O}$ ). Shukla et al., (2009) found the rate of $66 \mathrm{~kg} \mathrm{ha}^{-1}$ of $\mathrm{K}_{2} \mathrm{O}$ responsible for the increase of 74 tons/ha in the production. 
Table (4): Mean values cane yield (ton/fed) for sugarcane varieties as affected by dry-off days and potassium fertilization.

\begin{tabular}{|c|c|c|c|c|c|c|c|c|c|}
\hline \multirow{3}{*}{$\begin{array}{l}\text { Varieties } \\
\text { (V) }\end{array}$} & \multirow{3}{*}{$\begin{array}{c}\text { Dry- } \\
\text { off } \\
\text { period } \\
\text { "day" } \\
\text { (D) }\end{array}$} & \multicolumn{8}{|c|}{ Potassium levels "kg $\mathrm{K}_{2} \mathrm{O}$ /fed" (K) } \\
\hline & & \multicolumn{4}{|c|}{$2017 / 2018$} & \multicolumn{4}{|c|}{$2018 / 2019$} \\
\hline & & $\mathbf{0}$ & 36 & 72 & Mean & $\mathbf{0}$ & 36 & 72 & Mean \\
\hline \multirow{2}{*}{$\begin{array}{l}\text { G.2003- } \\
47\end{array}$} & 30 & 40.00 & 43.60 & 49.90 & 44.50 & 47.96 & $\mathbf{5 1 . 8 0}$ & 54.46 & 51.41 \\
\hline & 45 & 34.46 & 40.90 & 45.23 & 42.20 & 38.66 & 45.43 & 49.56 & 44.55 \\
\hline \multicolumn{2}{|l|}{ Mean } & 37.23 & 42.25 & 47.56 & 42.55 & 43.31 & 48.62 & 52.01 & 47.98 \\
\hline \multirow{2}{*}{$\begin{array}{l}\text { G.2003- } \\
49\end{array}$} & 30 & 40.66 & 45.16 & 48.76 & 44.86 & 45.10 & 48.23 & 52.00 & 48.44 \\
\hline & 45 & 36.46 & 40.50 & 43.30 & 40.09 & 40.90 & 45.16 & 48.03 & 44.70 \\
\hline \multicolumn{2}{|l|}{ Mean } & 38.56 & 42.83 & 46.03 & 42.47 & 43.00 & 46.70 & 50.02 & 46.57 \\
\hline \multirow{2}{*}{ G.84-47 } & 30 & 34.60 & 41.26 & 45.90 & 40.59 & 43.06 & 45.43 & 48.30 & 45.60 \\
\hline & 45 & 32.26 & 35.40 & 42.20 & 36.62 & 36.26 & 40.53 & 45.73 & 40.84 \\
\hline \multicolumn{2}{|l|}{ Mean } & 33.43 & 38.33 & 44.05 & 38.60 & 39.66 & 42.98 & 47.02 & 43.22 \\
\hline \multirow{2}{*}{$\begin{array}{l}\text { G.2004- } \\
27\end{array}$} & 30 & 37.40 & 41.90 & 45.10 & 41.47 & 37.10 & 42.20 & 44.56 & 41.29 \\
\hline & 45 & 32.48 & 35.36 & 41.00 & 36.28 & 33.26 & 39.10 & 42.50 & 38.29 \\
\hline \multicolumn{2}{|l|}{ Mean } & 34.94 & 38.63 & 43.05 & 38.87 & 35.18 & 40.65 & 43.53 & 39.79 \\
\hline \multirow{2}{*}{ GT54-9 } & 30 & 37.90 & 41.40 & 47.80 & 42.37 & 40.33 & 44.86 & 47.30 & 44.16 \\
\hline & 45 & 33.03 & 35.10 & 42.20 & 36.78 & 36.36 & 41.46 & 45.20 & 41.01 \\
\hline \multicolumn{2}{|l|}{ Mean } & 35.46 & 38.25 & 45.00 & 39.57 & 38.35 & 43.16 & 46.25 & 42.59 \\
\hline \multirow{2}{*}{$\begin{array}{l}\text { Mean of } \\
\text { D x K }\end{array}$} & 30 & 38.11 & 42.66 & 47.49 & 42.76 & 42.71 & 46.50 & 49.32 & 46.18 \\
\hline & 45 & 33.74 & 37.45 & 42.79 & 38.39 & 37.09 & 42.34 & 46.20 & 41.88 \\
\hline \multicolumn{2}{|l|}{ Mean } & 35.93 & 40.06 & 45.14 & 40.58 & 39.90 & 44.42 & 47.76 & 44.03 \\
\hline \multicolumn{2}{|l|}{$\mathbf{V}$} & & & & 0.85 & & & & 0.84 \\
\hline \multicolumn{2}{|l|}{$\mathbf{K}$} & & & & 0.45 & & & & 0.53 \\
\hline \multicolumn{2}{|l|}{ D } & & & & 0.63 & & & & 0.74 \\
\hline \multicolumn{2}{|l|}{$V \times K$} & & & & NS & & & & NS \\
\hline \multicolumn{2}{|l|}{$V \times D$} & & & & 1.34 & & & & 1.11 \\
\hline \multicolumn{2}{|l|}{ K x D } & & & & NS & & & & NS \\
\hline \multicolumn{2}{|l|}{$V \times K \times D$} & & & & NS & & & & 1.92 \\
\hline
\end{tabular}

Effect of drying-off and $\mathrm{K}$ fertilizer on Brix\% content

The results in table (5) showed that there were significant differences between the evaluated varieties for brix \%, as well as between dry-off days and potassium fertilizer levels in both seasons. The Brix\% increased with raising dry-off from 30 to 45 days in both seasons. Hagos $\boldsymbol{e t}$ $\boldsymbol{a l}$, (2014) found that the lowest brix\% in all stalk parts was obtained on the shortest drying off period ( 25 days), comparatively, longer drying off periods ( 65 and 85 days) showed greater brix content than the shorter drying off periods ( 25 and 45 days). The results showed that the highest value $(21.12 \%)$ was recorded with $72 \mathrm{~kg} \mathrm{~K} \mathrm{~K}_{2} \mathrm{O} /$ fed in plant cane and $(20.38 \%)$ with in the $1^{\text {st }}$ ratoon. The highest values of brix $(20.40 \%)$ were recorded with G.2004-27 variety in the plant cane and (20.46\%) with GT54-9 variety in the $1^{\text {st }}$ ratoon. Difference among cane varieties in this trait was found by AbuEllail et al., (2019) and Masri et al., (2014). Data indicated that significant interaction between potassium fertilizer and both of varieties and withholding irrigation treatment for both of sugarcane crops with repeat to the values of Brix\%, where, the highest values of Brix\% were recoded between $72 \mathrm{~kg} \mathrm{k2o} /$ fed with 45 days' dray-off in the plant cane and first 
ratoon. Moreover, the combinations between $72 \mathrm{~kg} \mathrm{k} 2 \mathrm{o} / \mathrm{fed}$ and the examined varieties attained the highest values of Brix\% with GT54/9 variety in both crops.

Table (5): Mean values of Brix\% as sugarcane varieties affected by dry-off days and potassium fertilization

\begin{tabular}{|c|c|c|c|c|c|c|c|c|c|}
\hline \multirow{3}{*}{$\begin{array}{c}\text { Varieties } \\
\text { (V) }\end{array}$} & \multirow{3}{*}{$\begin{array}{l}\text { Dry-off } \\
\text { period } \\
\text { "day" } \\
\text { (D) }\end{array}$} & \multicolumn{8}{|c|}{ Potassium levels "kg $\mathrm{K}_{2} \mathrm{O} / \mathrm{fed"}$ (K) } \\
\hline & & \multicolumn{4}{|c|}{$2017 / 2018$} & \multicolumn{4}{|c|}{$2018 / 2019$} \\
\hline & & $\mathbf{0}$ & 36 & 72 & Mean & $\mathbf{0}$ & 36 & 72 & Mean \\
\hline \multirow{2}{*}{ G.2003-47 } & 30 & 18.16 & 19.50 & 20.90 & 19.52 & 19.40 & 19.96 & 20.83 & 20.06 \\
\hline & 45 & 19.77 & 20.96 & 21.90 & 20.88 & 19.80 & 20.43 & 21.56 & 20.60 \\
\hline \multicolumn{2}{|l|}{ Mean } & 18.97 & 20.23 & 21.40 & 20.20 & 19.60 & 20.20 & 21.20 & 20.33 \\
\hline \multirow{2}{*}{ G.2003-49 } & 30 & 18.40 & 19.40 & 20.16 & 19.32 & 18.43 & 19.53 & 20.20 & 19.38 \\
\hline & 45 & 20.40 & 21.50 & 21.90 & 21.43 & 18.53 & 19.03 & 20.60 & 19.38 \\
\hline \multicolumn{2}{|l|}{ Mean } & 19.40 & 20.45 & 21.28 & 20.37 & 18.48 & 19.28 & 20.40 & 19.38 \\
\hline \multirow{2}{*}{ G.84-47 } & 30 & 17.80 & 18.40 & 19.40 & 18.53 & 17.73 & 18.76 & 19.83 & 18.77 \\
\hline & 45 & 18.96 & 19.90 & 21.30 & 20.05 & 18.13 & 19.00 & 19.86 & 19.00 \\
\hline \multicolumn{2}{|l|}{ Mean } & 18.38 & 19.15 & 20.35 & 19.29 & 17.93 & 18.88 & 19.85 & 18.88 \\
\hline \multirow{2}{*}{ G.2004-27 } & 30 & 18.83 & 19.50 & 20.23 & 19.52 & 16.90 & 17.73 & 18.33 & 17.65 \\
\hline & 45 & 19.90 & 21.90 & 22.03 & 21.27 & 17.90 & 18.23 & 19.70 & 18.61 \\
\hline \multicolumn{2}{|l|}{ Mean } & 19.36 & 20.70 & 21.13 & 20.40 & 17.40 & 17.98 & 19.01 & 18.13 \\
\hline \multirow{2}{*}{ GT54-9 } & 30 & 17.66 & 18.60 & 20.56 & 18.94 & 19.66 & 20.26 & 21.50 & 20.47 \\
\hline & 45 & 20.56 & 21.70 & 22.36 & 21.54 & 20.13 & 19.83 & 21.36 & 20.44 \\
\hline \multicolumn{2}{|l|}{ Mean } & 19.11 & 20.15 & 21.46 & 20.24 & 19.90 & 20.05 & 21.43 & 20.46 \\
\hline \multirow{2}{*}{$\begin{array}{l}\text { Mean of } \\
\text { D x K }\end{array}$} & 30 & 18.17 & 19.08 & 20.25 & 19.17 & 18.42 & 19.25 & 20.14 & 19.27 \\
\hline & 45 & 19.92 & 21.19 & 21.90 & 21.03 & 18.90 & 19.30 & 20.62 & 19.61 \\
\hline \multicolumn{2}{|l|}{ Mean } & 19.04 & 20.14 & 21.12 & 20.10 & 18.66 & 19.28 & 20.38 & 19.44 \\
\hline \multicolumn{2}{|l|}{$\mathbf{V}$} & & & & 0.23 & & & & 0.35 \\
\hline \multicolumn{2}{|l|}{$\mathbf{K}$} & & & & 0.15 & & & & 0.18 \\
\hline \multicolumn{2}{|l|}{ D } & & & & 0.22 & & & & 0.26 \\
\hline \multicolumn{2}{|l|}{$V \times K$} & & & & 0.27 & & & & 0.32 \\
\hline \multicolumn{2}{|l|}{$V \times D$} & & & & NS & & & & NS \\
\hline \multicolumn{2}{|l|}{ K x D } & & & & 0.46 & & & & 0.56 \\
\hline \multicolumn{2}{|l|}{$V \times K \times D$} & & & & 0.65 & & & & NS \\
\hline
\end{tabular}

Effect of drying-off and $\mathrm{K}$ fertilizer on sucrose content (\%):

The results in Table (6) showed that there is a significant change in sucrose content by dry-off days (from 15.44 to $15.91 \%$ ) in cane plant, and (15.96 to $16.56 \%$ ) in the $1^{\text {st }}$ ratoon. The days required for pre-harvest drying-off to improve sucrose accumulation in sugarcane could range from 30 to 45 days depending on low to high water holding capacity of the soil. The complete suspension of irrigation for the final two months before harvest gave the best results of soluble solids and sucrose content in South African sugarcane industries (Robertson and Donaldson, 1998) . The severest water deficit did not generally lead to a reduction in the production of sugar by the plant. This is due to the fact that in the water stressed conditions, the carbohydrates assimilated resulting from the photosynthesis process contributes preferentially to the activity of sucrose production and not to growth and development of stems, which is reduced (Aabad et al., 2017 ) . 
Table (6): Mean values of sucrose\% sugarcane varieties as affected by dry-off days and potassium fertilization

\begin{tabular}{|c|c|c|c|c|c|c|c|c|c|}
\hline \multirow{3}{*}{$\begin{array}{c}\text { Varieties } \\
\text { (V) }\end{array}$} & \multirow{3}{*}{$\begin{array}{c}\text { Dry- } \\
\text { off } \\
\text { period } \\
\text { "day" } \\
\text { (D) }\end{array}$} & & \multicolumn{7}{|c|}{ Potassium levels "kg K $\mathrm{K}_{2} \mathrm{O}$ /fed" (K) } \\
\hline & & \multicolumn{4}{|c|}{$2017 / 2018$} & \multicolumn{4}{|c|}{ 2018/2019 } \\
\hline & & $\mathbf{0}$ & 36 & 72 & Mean & $\mathbf{0}$ & 36 & 72 & Mean \\
\hline \multirow{2}{*}{$\begin{array}{l}\text { G.2003- } \\
47\end{array}$} & 30 & 14.80 & 15.76 & 16.10 & 15.55 & 14.46 & 15.46 & 15.93 & 15.28 \\
\hline & 45 & 15.90 & 16.63 & 16.46 & 16.33 & 15.20 & 16.10 & 17.13 & 16.14 \\
\hline \multicolumn{2}{|l|}{ Mean } & 15.35 & 16.20 & 16.28 & 15.94 & 14.83 & 15.78 & 16.53 & 15.71 \\
\hline \multirow{2}{*}{$\begin{array}{l}\text { G.2003- } \\
49\end{array}$} & 30 & 14.10 & 14.60 & 15.93 & 14.88 & 15.33 & 16.20 & 17.03 & 16.18 \\
\hline & 45 & 15.03 & 16.03 & 16.73 & 15.93 & 16.46 & 16.73 & 17.53 & 16.91 \\
\hline \multicolumn{2}{|l|}{ Mean } & 14.56 & 15.31 & 16.33 & 15.40 & 14.83 & 16.46 & 17.28 & 16.55 \\
\hline \multirow{2}{*}{ G.84-47 } & 30 & 15.10 & 15.60 & 16.43 & 15.71 & 15.50 & 16.80 & 17.26 & 16.52 \\
\hline & 45 & 15.70 & 16.10 & 16.13 & 15.98 & 16.60 & $\mathbf{1 7 . 2 6}$ & 17.40 & 17.08 \\
\hline \multicolumn{2}{|l|}{ Mean } & 15.40 & 15.85 & 16.78 & 16.01 & 16.05 & 17.03 & 17.33 & 16.80 \\
\hline \multirow{2}{*}{$\begin{array}{l}\text { G.2004- } \\
27\end{array}$} & 30 & 15.10 & 15.60 & 16.83 & 15.84 & 15.36 & 15.93 & 16.73 & 16.01 \\
\hline & 45 & 15.73 & 16.16 & 16.20 & 16.03 & 15.10 & 16.56 & 17.30 & 16.32 \\
\hline \multicolumn{2}{|l|}{ Mean } & 15.41 & 15.88 & 16.34 & 15.88 & 15.23 & 16.25 & 17.01 & 16.16 \\
\hline \multirow{2}{*}{ GT54-9 } & 30 & 14.10 & 15.10 & 16.43 & 15.21 & 14.60 & 15.46 & 17.36 & 15.81 \\
\hline & 45 & 14.55 & 15.30 & 16.06 & 15.30 & 15.53 & 16.56 & 16.90 & 16.33 \\
\hline \multicolumn{2}{|l|}{ Mean } & 14.32 & 15.20 & 16.75 & 15.42 & 15.06 & 16.01 & 17.13 & 16.07 \\
\hline \multirow{2}{*}{$\begin{array}{l}\text { Mean of } \\
\text { D x K }\end{array}$} & 30 & 14.64 & 15.33 & 16.34 & 15.44 & 15.05 & 15.97 & 16.86 & 15.96 \\
\hline & 45 & 15.38 & 16.04 & 16.32 & 15.91 & 15.78 & 16.64 & 17.25 & 16.56 \\
\hline \multicolumn{2}{|l|}{ Mean } & 15.01 & 15.69 & 16.50 & 15.73 & 15.20 & 16.31 & 17.06 & 16.26 \\
\hline \multicolumn{2}{|l|}{$\mathbf{V}$} & & & & 0.10 & & & & 1.02 \\
\hline \multicolumn{2}{|l|}{$\mathbf{K}$} & & & & 0.13 & & & & 0.25 \\
\hline \multicolumn{2}{|l|}{ D } & & & & 0.18 & & & & 0.35 \\
\hline \multicolumn{2}{|l|}{$V \times K$} & & & & 0.24 & & & & 0.38 \\
\hline \multicolumn{2}{|l|}{$\mathrm{V} \times \mathrm{D}$} & & & & 0.34 & & & & NS \\
\hline \multicolumn{2}{|l|}{ K x D } & & & & 0.41 & & & & 0.66 \\
\hline \multicolumn{2}{|l|}{$V \times K \times D$} & & & & 0.58 & & & & NS \\
\hline
\end{tabular}

On the other side, adding $72 \mathrm{~kg} \mathrm{~K} 2 \mathrm{O} /$ fed led to the highest value of sucrose $\%(16.50 \%)$ in plant cane and $(17.06 \%)$ in the $1^{\text {st }}$ ratoon, also, the highest value (16.01\%) was recorded with G.84/47 variety in cane plant, and $(16.80 \%)$ with the same variety in the $1^{\text {st }}$ ratoon. On the other hand, the factors such as climate, cultivar and soil management affect the amount of accumulated sugar in cane yield, making it difficult to evaluate the fertilizer effect on this parameter (Pereira et al., 1995).

Data in Table (6) illustrated that sucrose\% was significantly affected by the most of interaction between treatments in both seasons, it was found that the increase in $\mathrm{K}$ fertilizer levels and increase in dry-off days were accompanied by a significant increase in sucrose\% with all examined varieties in the cane plant and $1^{\text {st }}$ ratoon except G.84/47, and G.2003-49 in the $1^{\text {st }}$ ratoon, sucrose $\%$ were decrease with increase dry-off days. Generally, sucrose\% was increasing with increase dry-off days and raising $\mathrm{K}$ fertilizer levels which were $(16.78$ and $16.80 \%)$ with $72 \mathrm{~kg} / \mathrm{K}_{2} \mathrm{O} / \mathrm{fed}$, and 30 dry-off day with G84/47 variety in the cane plant and first ratoon respectively. The increase in potassium supply to the soil is more important to cane yield than to the technological quality of $1^{\text {st }}$ ratoon sugarcane, fact also reported by Feltrin $\boldsymbol{e t}$ al., (2010). Therefore, the effects of potassium on 
quality are contradictory because genetics, soil and climate conditions are distinct among the experiments. It acts as a specific activator of the enzyme inverses in the synthesis of sucrose in sugarcane crop (Singh et al., 2009).

\section{Effect of drying-off and $K$ fertilizer on sugar recovery \%:}

Data in Table (7) showed that there was significant interaction between dry-off days, potassium levels and sugar cane varieties for sugar recovery\% in both seasons except the interaction between sugar cane varieties and potassium fertilizers. The $72 \mathrm{~kg} \mathrm{~K}_{2} \mathrm{O} /$ fed had the highest value $(10.69 \%)$ in cane plant, and $(11.48 \%)$ in the $1^{\text {st }}$ ratoon. Sugar recovery\% was decreased with raising dry-off days from 30 to 45 days from (10.18 to $10.12 \%)$ in cane plant, while led to an increase from (10.68 to $1119 \%)$ in the $1^{\text {st }}$ ratoon. Olivier $\boldsymbol{e t}$ al., (2006) indicated that sugar recovery\% increased with raising of potassium fertilizer levels. There was a small and significant reduction in the juice content with $\mathrm{K}$ fertilization. This decrease was only $3.7 \%$ compared to the initial content, reaching 162.9 with $101.9 \mathrm{~kg} \mathrm{~K} 2 \mathrm{O} / \mathrm{ha}$ (Márcio et al., 2015). Concerning sugar recovery\% and its relation with sugarcane varieties, it could be noticed that the studied varieties appeared significant difference in this respect, between, it would be concluded that sugarcane varity G.84-47 recorded the highest values of sugar recovery ie. $10.73 \%$ and $11.66 \%$ in the plant cane and the first ratoon.

Table (7): Mean values of sugar recovery \% for sugarcane varieties as affected by dry-off days and potassium fertilization

\begin{tabular}{|c|c|c|c|c|c|c|c|c|c|}
\hline \multirow{3}{*}{$\begin{array}{c}\text { Varieties } \\
\text { (V) }\end{array}$} & \multirow{3}{*}{$\begin{array}{c}\text { Dry-off } \\
\text { period } \\
\text { "day" } \\
\text { (D) }\end{array}$} & & \multicolumn{7}{|c|}{ Potassium levels "kg $\mathrm{K}_{2} \mathrm{O}$ /fed" (K) } \\
\hline & & \multicolumn{4}{|c|}{$2017 / 2018$} & \multicolumn{4}{|c|}{$2018 / 2019$} \\
\hline & & $\mathbf{0}$ & 36 & 72 & Mean & $\mathbf{0}$ & 36 & 72 & Mean \\
\hline \multirow{2}{*}{$\begin{array}{l}\text { G.2003- } \\
47\end{array}$} & 30 & 9.82 & 10.42 & $\mathbf{1 0 . 3 5}$ & 10.19 & 9.12 & 9.97 & 10.20 & 9.76 \\
\hline & 45 & 10.47 & 10.87 & $\mathbf{1 0 . 4 3}$ & 10.59 & 9.75 & 10.48 & 11.21 & 10.48 \\
\hline \multicolumn{2}{|l|}{ Mean } & $\mathbf{1 0 . 1 4}$ & 10.64 & 10.39 & 10.39 & 9.43 & $\mathbf{1 0 . 2 3}$ & $\mathbf{1 0 . 7 0}$ & 10.12 \\
\hline \multirow{2}{*}{$\begin{array}{l}\text { G.2003- } \\
49\end{array}$} & 30 & 9.03 & 9.25 & 10.39 & 9.57 & $\mathbf{1 0 . 2 8}$ & $\mathbf{1 0 . 8 5}$ & $\mathbf{1 1 . 5 1}$ & 10.88 \\
\hline & 45 & 9.41 & $\mathbf{1 0 . 1 0}$ & $\mathbf{1 0 . 7 0}$ & 10.02 & 11.41 & 11.54 & 11.90 & 11.62 \\
\hline \multicolumn{2}{|l|}{ Mean } & 9.22 & 9.68 & 10.48 & 9.79 & 10.85 & 11.19 & 11.70 & 11.25 \\
\hline \multirow{2}{*}{ G.84-47 } & 30 & 10.23 & 10.57 & 11.13 & 10.64 & 10.66 & 11.69 & 11.85 & 11.40 \\
\hline & 45 & 10.50 & 10.64 & 10.27 & 10.48 & 11.67 & 12.09 & 11.98 & 11.91 \\
\hline \multicolumn{2}{|l|}{ Mean } & 10.37 & 10.60 & 11.21 & 10.73 & 11.16 & 11.89 & 11.92 & 11.66 \\
\hline \multirow{2}{*}{$\begin{array}{l}\text { G.2004- } \\
27\end{array}$} & 30 & 9.93 & 10.25 & 11.29 & 10.49 & 10.77 & 11.10 & 11.74 & 11.20 \\
\hline & 45 & 10.27 & 10.13 & 10.12 & 10.17 & 10.20 & 11.61 & 11.93 & 11.24 \\
\hline \multicolumn{2}{|l|}{ Mean } & 10.10 & 10.19 & 10.53 & 10.27 & 10.48 & 11.35 & 11.83 & 11.22 \\
\hline \multirow{2}{*}{ GT54-9 } & 30 & 9.25 & 10.00 & 10.79 & 10.01 & 9.17 & 9.89 & 11.47 & 10.18 \\
\hline & 45 & 8.86 & 9.30 & 9.88 & 9.35 & 9.99 & 11.14 & 11.03 & 10.72 \\
\hline \multicolumn{2}{|l|}{ Mean } & 9.05 & 9.65 & 10.85 & 9.85 & 9.58 & 10.51 & 11.25 & 10.45 \\
\hline \multirow{2}{*}{$\begin{array}{l}\text { Mean of } \\
\text { D X K }\end{array}$} & 30 & 9.65 & 10.10 & 10.79 & 10.18 & 10.00 & 10.70 & 11.35 & 10.68 \\
\hline & 45 & 9.90 & 10.21 & 10.28 & 10.12 & 10.60 & 11.37 & 11.61 & 11.19 \\
\hline \multicolumn{2}{|l|}{ Mean } & 9.78 & 10.15 & 10.69 & 10.21 & 10.30 & 11.03 & 11.48 & 10.94 \\
\hline \multicolumn{2}{|l|}{$\mathbf{V}$} & & & & 0.13 & & & & 0.11 \\
\hline \multicolumn{2}{|l|}{$\mathbf{K}$} & & & & 0.14 & & & & 0.25 \\
\hline \multicolumn{2}{|l|}{ D } & & & & 0.19 & & & & 0.35 \\
\hline \multicolumn{2}{|l|}{$V \times K$} & & & & NS & & & & NS \\
\hline \multicolumn{2}{|l|}{$V \times D$} & & & & 0.37 & & & & NS \\
\hline \multicolumn{2}{|l|}{ K x D } & & & & 0.45 & & & & 0.63 \\
\hline \multicolumn{2}{|l|}{ V x K x D } & & & & 0.64 & & & & NS \\
\hline
\end{tabular}


Sugar recovery\% was increased with raising potassium levels from 36 to $72 \mathrm{~kg} \mathrm{~K} 2 \mathrm{O} / \mathrm{fed}$ with raising dry-off days from 30 to 45 days, it was significantly increasing in sugar recovery\%. The highest value $(11.29 \%)$ was attained with $72 \mathrm{~kg} \mathrm{~K}_{2} \mathrm{O} / \mathrm{fed}$ at 30 dry-off days with G.2004-27 in cane plant, but it was (11.98\%) with $72 \mathrm{~kg} \mathrm{~K}_{2} \mathrm{O} / \mathrm{fed}$ at 45 dry-off days with G.8447 in the $1^{\text {st }}$ ratoon. Abu-Ellail at al., (2018 and 2019) found that the genotype $x$ crop mean squares were highly significant $(\mathrm{P}<0.01)$ for the characters under this experiment.

\section{Effect of drying-off and $K$ fertilizer on purity\%:}

Means listed in Table (8) showed a significant difference between sugar cane varieties for purity\% under dry-off days and potassium levels in both seasons. The results elucidate that purity $\%$ was significantly decreased with raising dry-off days from 30 to 45 days (80.59 to $75.73 \%$ ) in plant cane, while it was increased from (83.10 to $84.67 \%)$ in the $1^{\text {st }}$ ratoon. Sugar recovery\% was reduced by decreasing purity\%, the increase of $\mathrm{K}$ from 36 to $72 \mathrm{~kg} \mathrm{~K} 2 \mathrm{O} / \mathrm{fed}$ led to a decrease for purity\% from (78.15 to $78.13 \%)$ in plant cane; also it was decreased from ( 84.83 to $83.93 \%$ ) in the $1^{\text {st }}$ ratoon. Juice purity and sugar concentration declined with increased the $K$ fertilizer (Gameh et al., 2015). There was differences significant among sugar cane varieties in both seasons for purity\%. The highest value of purity\% (83.00\%) was recorded with G.84-47 in the cane plant, while in the $1^{\text {st }}$ ratoon, the highest value $(89.21 \%)$ was recorded with G.2004-27 variety.

Table (8): Mean values of purity\% for sugarcane varieties as affected by dry-off days and potassium fertilization

\begin{tabular}{|c|c|c|c|c|c|c|c|c|c|}
\hline \multirow{3}{*}{$\begin{array}{l}\text { Varieties } \\
(\mathbf{V})\end{array}$} & \multirow{3}{*}{$\begin{array}{l}\text { Dry-off } \\
\text { period } \\
\text { "day" } \\
\text { (D) }\end{array}$} & \multicolumn{8}{|c|}{ Potassium levels "kg $\mathrm{K}_{2} \mathrm{O} /$ fed" (K) } \\
\hline & & \multicolumn{4}{|c|}{$2017 / 2018$} & \multicolumn{4}{|c|}{$2018 / 2019$} \\
\hline & & $\mathbf{0}$ & 36 & 72 & Mean & 0 & 36 & 72 & Mean \\
\hline \multirow{2}{*}{ G.2003-47 } & 30 & 81.51 & 80.92 & 77.03 & 79.68 & 74.60 & $\mathbf{7 7 . 5 0}$ & 76.45 & 76.18 \\
\hline & 45 & 80.44 & 79.36 & 75.16 & $\begin{array}{l}78.21 \\
\end{array}$ & 76.77 & 78.80 & 79.48 & 78.35 \\
\hline \multicolumn{2}{|l|}{ Mean } & 80.98 & 80.14 & 76.07 & 78.93 & 75.68 & 78.15 & 77.96 & 77.27 \\
\hline \multirow{2}{*}{ G.2003-49 } & 30 & 76.71 & 75.31 & 79.02 & 77.00 & 83.13 & 82.96 & 84.33 & 83.47 \\
\hline & 45 & 73.71 & 74.58 & 76.39 & 74.34 & $\mathbf{8 8 . 8 5}$ & 87.94 & 85.13 & 87.31 \\
\hline \multicolumn{2}{|l|}{ Mean } & 75.21 & 74.94 & 76.74 & 75.60 & 85.99 & 85.45 & 84.73 & 85.39 \\
\hline \multirow{2}{*}{ G.84-47 } & 30 & 84.87 & 84.77 & 84.69 & 84.78 & 87.39 & 89.54 & 87.06 & 87.99 \\
\hline & 45 & 82.81 & 80.96 & 75.73 & 79.68 & 91.47 & 90.96 & 87.63 & 90.02 \\
\hline \multicolumn{2}{|l|}{ Mean } & 83.84 & 82.87 & 82.46 & 83.00 & 89.43 & 90.25 & 87.34 & 89.01 \\
\hline \multirow{2}{*}{ G.2004-27 } & 30 & 80.16 & 80.02 & 83.19 & 81.16 & 91.05 & 89.86 & 91.28 & 90.73 \\
\hline & 45 & 79.07 & 73.82 & 73.54 & 75.36 & 84.40 & 90.84 & 87.84 & 87.69 \\
\hline \multicolumn{2}{|l|}{ Mean } & 79.61 & 76.92 & 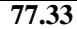 & $\begin{array}{l}77.83 \\
\end{array}$ & 87.72 & 90.35 & 89.56 & 89.21 \\
\hline \multirow{2}{*}{ GT54-9 } & 30 & 79.84 & 81.24 & 79.91 & 80.31 & 74.21 & 76.30 & 80.88 & 77.13 \\
\hline & 45 & 70.79 & 70.53 & 71.82 & 71.05 & 77.13 & 83.57 & 79.23 & 79.98 \\
\hline \multicolumn{2}{|l|}{ Mean } & 75.31 & 75.89 & 78.05 & 76.20 & 75.67 & 79.94 & 80.05 & 87.55 \\
\hline \multirow{2}{*}{$\begin{array}{l}\text { Mean of } \\
\text { D X K }\end{array}$} & 30 & 80.62 & 80.45 & 80.77 & 80.59 & 82.08 & 83.23 & 84.00 & 83.10 \\
\hline & 45 & 77.36 & 75.85 & 74.53 & 75.73 & 83.72 & 86.42 & 83.86 & 84.67 \\
\hline \multicolumn{2}{|l|}{ Mean } & 78.99 & 78.15 & 78.13 & 78.31 & 82.90 & 84.83 & 83.93 & 83.89 \\
\hline \multicolumn{2}{|l|}{ V } & & & & 0.23 & & & & 0.45 \\
\hline \multicolumn{2}{|l|}{$\mathbf{K}$} & & & & 0.87 & & & & 1.40 \\
\hline \multicolumn{2}{|l|}{ D } & & & & 1.23 & & & & 1.98 \\
\hline \multicolumn{2}{|l|}{ V $\times K$} & & & & 1.66 & & & & 2.01 \\
\hline \multicolumn{2}{|l|}{ VXD } & & & & NS & & & & 2.84 \\
\hline \multicolumn{2}{|l|}{ K X D } & & & & NS & & & & NS \\
\hline \multicolumn{2}{|l|}{$V \times K \times D$} & & & & NS & & & & NS \\
\hline
\end{tabular}


Data in Table (8) elucidate that there were significant interaction effects between dry-off days, $\mathrm{K}$ fertilizer levels and sugar cane varieties for purity\% in both seasons except the first order interaction $\left(K^{*} \mathrm{D}\right)$ and the second order interaction $\left(\mathrm{V}^{*} \mathrm{~K}^{*} \mathrm{D}\right)$. Increase dry-off days from 30 to 45 days was accompanied by significant decrease in purity in both seasons. On the contrary, increases $\mathrm{K}$ fertilizer level decreased in purity\%, nevertheless, the sugar cane varieties were significantly affected on purity, the highest value of purity\% (82.46 \%) was recorded with G.84-47 with zero K fertilizer level at 30 dry-off day in the cane plant, while the highest value $(91.28 \%)$ was recorded with G.2004-27 at 30 dry-off day and zero k fertilizer level in the $1^{\text {st }}$ ratoon.

\section{Effect of drying-off and $K$ fertilizer on sugar yield:}

Data in Table (9) cleared that the sugar yield was significantly affected by dry-off days, potassium levels and sugar cane varieties in both seasons. The sugar yield was significant decreased with raising dry off from 30 to 45 days from ( 4.35 to 3.85 ton/fed) in plant cane and (4.92 to $4.68 \mathrm{ton} / \mathrm{fed}$ ) in $1^{\text {st }}$ ratoon. On the other side sugar yield was significantly increased with increasing potassium fertilizer levels from (zero to $72 \mathrm{~kg} / \mathrm{fed}$.) recorded (4.07 to $4.82 \mathrm{ton} / \mathrm{fed}$ ) in cane plant and there also increasing from (4.89 to 5.47 ton/fed) at $1^{\text {st }}$ ratoon.

Sugar yield was significantly differed between the examined varieties in both seasons, where, the highest value (4.40 ton/fed) was according with G.2003-47 in cane plant and (5.24 ton/fed) with G.200349 in the $1^{\text {st }}$ ratoon. Differences among cane varieties in these traits were found by Masri et al., (2014) and Bekheet (2006) who showed that increasing the applied $\mathrm{K}$ levels up to $75 \mathrm{~kg} \mathrm{~K}_{2} \mathrm{O} /$ fed increased sucrose and sugar recovery percentages and yields of cane and sugar. Singh $\boldsymbol{e t}$ al., (1999) reported that potassium application had no significant effect on cane yield but increased commercial cane sugar content.

Data in Table (9) indicated that significant interaction effects between dry-off days, $\mathrm{K}$ fertilizer levels and sugar cane varieties for sugar yield in both seasons. The highest value of sugar yield (5.16 ton/fed) was recorded with $72 \mathrm{~kg} \mathrm{~K} \mathrm{~K}_{2} \mathrm{O} / \mathrm{fed}$ and 30 dry-off days with G.2003-47 in plant cane, while in the $1^{\text {st }}$ ratoon, the highest value (5.99 ton/fed) was given by $72 \mathrm{~kg} \mathrm{~K} 2 \mathrm{O} / \mathrm{fed}$ at 30 dry-off days with G.2003-49 variety. Since $\mathrm{K}$ is very relevant in sugarcane growth, development, yield and quality, knowledge of the potassium distribution is of great importance for many research areas (Nilberto et al., 2013). AbouSalama, (1995) reported that potassium application of $50-100 \mathrm{~kg}$ $\mathrm{K}_{2} \mathrm{O} /$ fed exhibited a significant effect on net cane and sugar yields. 
Table (9): Mean values of sugar yield \% for sugarcane varieties as affected by dry-off days, potassium fertilization and varieties.

\begin{tabular}{|c|c|c|c|c|c|c|c|c|c|}
\hline \multirow{3}{*}{$\begin{array}{c}\text { Varieties } \\
\text { (V) }\end{array}$} & \multirow{3}{*}{$\begin{array}{l}\text { Dry-off } \\
\text { period } \\
\text { "day" } \\
\text { (D) }\end{array}$} & \multicolumn{8}{|c|}{ Potassium levels" $" k g \mathrm{~K}_{2} \mathrm{O} /$ fed" (K) } \\
\hline & & \multicolumn{4}{|c|}{$2017 / 2018$} & \multicolumn{4}{|c|}{ 2018/2019 } \\
\hline & & $\mathbf{0}$ & 36 & 72 & Mean & $\mathbf{0}$ & 36 & 72 & Mean \\
\hline \multirow{2}{*}{ G.2003-47 } & 30 & 3.93 & 4.54 & 5.16 & 4.53 & 4.37 & 5.16 & 5.55 & 5.02 \\
\hline & 45 & 3.61 & 4.45 & 4.72 & 4.26 & 3.77 & 4.76 & 5.56 & 4.67 \\
\hline \multicolumn{2}{|l|}{ Mean } & 3.78 & 4.50 & 4.94 & 4.40 & 4.08 & 4.97 & 5.57 & 4.86 \\
\hline \multirow{2}{*}{ G.2003-49 } & 30 & 3.67 & 4.18 & 5.07 & 4.29 & 4.64 & 5.23 & 5.99 & 5.27 \\
\hline & 45 & 3.43 & 4.09 & 4.63 & 4.02 & 4.67 & 5.21 & 5.72 & 5.19 \\
\hline \multicolumn{2}{|l|}{ Mean } & 3.56 & 4.15 & 4.82 & 4.16 & 4.67 & 5.23 & 5.85 & 5.24 \\
\hline \multirow{2}{*}{ G.84-47 } & 30 & 3.54 & 4.36 & 5.11 & 4.32 & 4.59 & 5.31 & 5.72 & 5.20 \\
\hline & 45 & 3.39 & 3.77 & 4.33 & 3.84 & 4.23 & 4.90 & 5.48 & 4.86 \\
\hline \multicolumn{2}{|l|}{ Mean } & 3.47 & 4.06 & 4.94 & 4.14 & 4.43 & 5.11 & 5.60 & 5.04 \\
\hline \multirow{2}{*}{ G.2004-27 } & 30 & 3.71 & 4.29 & 5.09 & 4.35 & 4.00 & 4.68 & 5.23 & 4.62 \\
\hline & 45 & 3.34 & 3.58 & 4.15 & 3.69 & 3.39 & 4.54 & 5.07 & 4.30 \\
\hline \multicolumn{2}{|l|}{ Mean } & $\mathbf{3 . 5 3}$ & 3.94 & 4.53 & 3.99 & 3.69 & 4.61 & 5.15 & 4.46 \\
\hline \multirow{2}{*}{ GT54-9 } & 30 & 3.51 & 4.14 & 5.16 & 4.24 & 3.70 & 4.44 & 5.43 & 4.50 \\
\hline & 45 & 2.93 & 3.26 & 4.17 & 3.44 & 3.63 & 4.62 & 4.99 & 4.40 \\
\hline \multicolumn{2}{|l|}{ Mean } & 3.21 & 3.69 & 4.88 & 3.90 & 3.67 & 4.54 & 5.20 & 4.45 \\
\hline \multirow{2}{*}{$\begin{array}{l}\text { Mean of } \\
\text { D x K }\end{array}$} & 30 & 3.67 & 4.30 & 5.12 & 4.35 & 4.26 & 4.96 & 5.58 & 4.92 \\
\hline & 45 & 3.34 & 3.83 & 4.40 & 3.85 & 3.94 & 4.81 & 5.36 & 4.68 \\
\hline \multicolumn{2}{|l|}{ Mean } & 3.51 & 4.07 & 4.82 & 4.12 & 4.11 & 4.89 & 5.47 & 4.81 \\
\hline \multicolumn{2}{|l|}{$\mathbf{V}$} & & & & 0.13 & & & & 0.14 \\
\hline \multicolumn{2}{|l|}{$\mathrm{K}$} & & & & 0.08 & & & & 0.10 \\
\hline \multicolumn{2}{|l|}{ D } & & & & 0.11 & & & & 0.13 \\
\hline \multicolumn{2}{|l|}{$V \times K$} & & & & NS & & & & NS \\
\hline \multicolumn{2}{|l|}{ V $x D$} & & & & 0.19 & & & & NS \\
\hline \multicolumn{2}{|l|}{ K x D } & & & & 0.23 & & & & 0.27 \\
\hline \multicolumn{2}{|l|}{$V \times K \times D$} & & & & 0.33 & & & & NS \\
\hline
\end{tabular}

\section{CONCLUSIONS}

The results concluded that the highest cane and sugar yields were recorded with sugar cane varieties, G.2003-47, G.2003-49, G.84/47 varieties, respectively, indicating that they are a greater promise, that can be evaluated in subsequent regional selection programs. Also, the best treated by $72 \mathrm{~kg} \mathrm{k2o} / \mathrm{fed}$ under the dry-off day of 30 days.

\section{REFERENCE}

Aabadi, M.; A. Bouaziz ; A. Falisse ; J.F. Martie and M. ELMessaoudi (2017). Improving yield and water use efficiency of sugarcane under drip irrigation in the Gharb region of Morocco. Rev. Mar. Sci. Agron. Vét., 5 (1):32-40.

Abd El-Hadi, A.H. (1989). Potassium and its effect on the productivity of crops on the Egyptian soils (Arabic). Published by Soil and Water Research Institute, Agric., Res., Center. 
Abd El-Hadi, A.H.; M.S. Khadr and M.A.M. Hassan (1990). Effect of fertilization on the productivity of major field crops under intensive cropping system in Egypt. $3^{\text {rd }}$ International Congress Program of Soil Science Society of Pakistan, March 20-22.

Abou-Salama, A.M. (1995): Studies on potassium fertilization of sugar cane. 1-Effect of fertilization rate and date on yield and quality. Assiut J. Agric.Sci., 26 (1):291-299.

Abu-Ellail, F.F.B. ; Y.M. Abd El-Azez and Nouran A Bassiony (2019). Assessment of ratooning ability and genetic variability of promising sugarcane varieties under middle Egypt conditions. Electronic Journal of Plant Breedin,10(1):143-154.

Abu-Ellail, F.F.B. ; A.B.A. El-Taib and M.I. Masri (2018). Performance of new sugarcane clones for yield and its components during two different crop cycles. Indian Journal of Sugarcane Technology., 33(01): 26-33.

Ahmed, M. ; K.P. Baiyeri and B.C. Echezona (2013). Effect of planting parts and potassium rate on the productivity of sugarcane (Saccharum officinarum L.). Exp. Agricult. Horticulture, 2(1): 23-30.

Alexander, W. P. (1926). Potash fertilization on Eva Plantation. Hawn. Planters' Record., 30:438.

A.O.A.C. (1995). Official methods of analysis of the Association of Official Analytical Chemists. 2 vols. 15th ed. Washington, DC.

Azeredo, D.F. and A.A. Peixoto (1978). Fertilizing of sugar cane with nitrogen, phosphorus and potassium. Brazil Acucariro, 91 (6): 20-26.

Bekheet, M.A. (2006). Effect of irrigation and potassium fertilization on yield and quality of two sugarcane varieties. Assiut J. Agric. Sci., 37(1): 1-19.

Blackburn, F. (1984). Sugar cane. Tropical Agriculture series, Longman, London.

Borden, R. J. (1938). Effect of sunlight on utilization of nitrogen and potash by cane.Int. Sug. J., 40:33-34.

Bregger, T. and M. R. Bedsole (1953). Physiology of sugar cane. Report Florida Agr. Exp. Sta., 232. 1953.

Daniel, H. (1982). Article from Introduction to soil physics. Academic press, Inc.

Davidson, L.G. and L.A. Hurst (1942). Soil fertility investigations on sugar cane in Louisiana. Sug. Bull., 21(3):20-22. 
El-Geddawy, Dalia I.H. ; B.S.I. Makhlouf and M.A. Bekhee (2015). Performance of Some Sugar Cane Promising Varieties under Different Seed Sett Rates and Potassium Fertilization Int. J0 of Current Microbiol. and Applied Sci., 4(11): 92-110.

El-Geddawy, L.H. ; M.S. Rady ; H.A. Dawwam ; A. Hendawy and R.A.M.A. El-Ghait (2005). Response of some sugar cane varieties to nitrogen and potassium application. Egypt. J. Agric. Res., 83(2): 693707.

Feltrin M.S. ; M.G.D.P. Lavanholi ; H.S. Silva and R.M. Prado (2010). Adubação potássica na produtividade da soqueira de cana-de-açúcar colhida sem queima. Nucleus., 7(1): 307-314.

Freed, E. ; J. Gailit ; P. van der Geer ; E. Ruoslahti and T. Hunter (1989). A novel integrin $\beta$ subunit is associated with the vitronectin receptor $\alpha$ subunit $(\alpha(\mathrm{v}))$ in a human osteosarcoma cell line and is a substrate for protein kinase C8. J. Embo., 10: 2955-2965.

Gameh, M.A.; E.M. Ahmed ; M.R. Dardiry and M.A.H. Gebreel (2015). Effect of Alternative Furrow Irrigation and Potassium Fertilization on Sugarcane Yield Assiut J. Agric. Sci., 46(2): 179-192.

Geerlings, H.C.P.(1911). The correlation between the sugar and potash contents of cane juice. Int. Sug. J., 13:417-421.

Hagos H. ; W. Worku and A. Takele (2014). Effect of Drying Off Period and Harvest Age on Quality and Yield of Ratoon Cane (Saccharium officinarium L.). Adv Crop Sci Tech 2:133. doi: 10.4172/2329-8863.1000133.

Husz, G. (1972). Sugar Cane. Cultivation and Fertilization. Series of Monographs on Tropical and Subtropical Crops. Ruhr-Stickstoff A.G., Bochum, West Germany.

Inman-Bamber, N.G. (2004). Sugarcane water stress criteria for irrigation and drying off in Australia. Field Crops Research., 89: 107-122.

Kakde, J.R. (1985). Suger cane production. Renu printers, New Delhi. India.

Mahmoud, S.A. ; B. Hasanin ; I.H. El-Geddawy and M.F.A. Mustafa (2008). Effect of some fertilization treatments on productivity and quality of the newly released sugarcane variety (PHIL.8013). Meeting the challenges of sugar crops 
andintergrated industries developing countries, Al Arish, Egypt. Pp. 313.

Mahmuod, E.A.; M.N. Bakr and A.Y. El-Bashbishi (1984). Response of ratoon crop of sugar cane to increasing levels of nitrogen and potassium. Second Conf., A.R.C., Giza.

Márcio, A. P. ; R. de M. Prado ; R. A. Flores ; H. J. de Almeida ; L. Ro. Moda1 and J.P. de S. Junior (2015). Growth, yield and nutrition of sugarcane ratoon as affected by potassium in a mechanized harvesting system. AJCS., 9(10):915-924.

Masri, M.I. ; Sh A Shaban ; H.H. El-Hennawy ; A.B.A. El-Taib and F.F.B. Abu-Ellail (2014). Evaluation of some sugarcane genotypes for yield and quality traits at the first clonal stage. Egyptian Journal of Applied Sciences., 29 (B 12). 709-730.

Medina, N.H.; M. L.T. Branco; M.A.G. Silveira and R.B.B.Santos (2013). Dynamic istribution of potassium in sugarcane. J. Environmental Radioactivity, 126:172-175.

Naquin, E.E. (1926). Potash at Honokaa. Hawn. Planters' Record. 30:459. Ulrich, A. Plant Testing. The American Potash Institute, Inc., Wash., D. C.

Nilberto, H.M.; M.L.T. Branco; M.A.G. Silveira and R.B.B. Santos. (2013). Dynamic distribution of potassium in sugarcane. $J$. Environmental Radioactivity, $126: 172-175$.

Olivier, F.C. ; R.A. Donaldson and S.A. single (2006). Drying off sugar cane on soils with low water holding capacity. Proc S Afr Sug Technol Ass,vol. 80, page 183 . (South African Sugarcane Research Institute, Private Bag X02, Mount Edgecombe, 4300, South Africa).

Otto, R. ; G.C. Vitti and P.H.C. Luz (2010). Potassium fertilizer management for sugarcane. Rev Bras Ci Solo., 34(4): 1137-1145.

Pereira, J.R. ; C.M.B. Faria and L.B. Morgado (1995). Effect of phosphorus application ando $\mathrm{f}$ its residue on the yield os sugarcane in a vertisol. Pesq Agropec Bras., 30(1): 43-48.

Pleskhow, B.P. (1976). Analysis in agriculture biochemistry. $2^{\text {nd }}$ Ed., Moscow, Kales.

Ramulu, U.S. (1998). Management of Water Resources in Agricultuire. New age International (P) Limited. New Delhi. India.

Robertson, M.J. and R.A. Donaldson (1998). Changes in the components of cane and sucrose yield in response to drying-off of sugarcane before harvest. Field Crops Research, 55: 201-208. 
Rossetto, R. ; A. Spironello ; H. Cantarella and J.A. Quaggio (2004). Sugarcane response to liming and potassium fertilization. Bragantia., 63(1): 105-119.

Samuels, G. and P. Jr. Landrau (1957). The influence of potassium on the yield and sucrose content of sugar cane. Soil Sci. Soc. Am. Proc. 19:66-69. 1955. and. The sucrose content of sugar cane as influenced by fertilizers. Sug. News., 33:380-386.

Samuels, G. ; M.A. Lugo-Lopez and P. Landrau (1952). Influence of fertilizers on sucrose content of sugar cane. Sug., 47:49. 1952.

Schultz, N. ; E. Lima ; M.G. Pereira and E. Zonta (2010). Residual effects of nitrogen, potassium and vinasse, fertilization on cane plant and ratoon harvested with and without straw burning. Rev Bras Ci Solo., 34(3): 811-820.

Shukla, S.K. ; R.L. Yadav ; P.N. Singh and I. Singh (2009). Potassium nutrition for improving stubble bud sprouting, dry matter partitioning, nutrient uptake and winter initiated sugarcane (Saccharum spp. hybrid complex) ratoon yield. European Journal of Agronomy, 30:27-33.

Singels, A. ; A.J. Kennedy and C.N. Bezuidenhout (2000). The effect of water stress on sugarcane biomass accumulation and partitioning. Proc S Afr Sug Technol Ass, 74: 169-172.

Singh, K.D.N. ; G.K. Mishra and J.B. Ojha (1999). Effect of potassium on yield and quality of sugarcane in calciothents. Ind. Sugar, 49(7): 499-507.

Singh, S.B. ; G.P. Rao ; S. Solomon and P. Gopalasundaram (2009). Sugarcane- Crop production and improvement. Studium Press LLC, Houstan, Texas, USA. pp.387-542.

Steel, R.G.D. ; J.H. Torrie and D.A. Dicky (1997). Principles and Procedures of Statistics, A Biometrical Approach. 3rd Edition, McGraw Hill, Inc. Book Co., New York, 352-358.

Stevens, F.D. (1933). Agronomic phases sugar cane investigation. Report Florida Agr.Exp. Sta.,Pp: 185.

Velasco, H.; A.S. Cid; R.M. Anjos; C. Zamboni; M. Rozzotto; D.L. Valladares and J.J. Ayub (2012). Variability of 137Cs and $40 \mathrm{~K}$ soil-to-fruit transfer factor in tropical lemon trees during the fruit development period. Journal of Environmental Radioactivity., 104: 64-70.

Verma, R.D.N. ; S.B. Singh ; M.L. Vishvakarma and T.N. Tiwari (1998). Optimum and economic dose of nitrogen, phosphorus 
and potash for autumn planted soils sugarcane in Bhat soils of U.P. Ind. Sugar., 48(6): 451453.

Verret, J. A. (1923). The effect of phosphoric acid and potash on the quality of cane juices. Hawn. Planters' Record., 27:117-121.

Yadav, R.L. and R.K. Sharma (1980). Effect of nitrogen levels and harvesting dates on quality characters and yield of four sugar cane genotypes. Indian J., 50 (7): 581 - 589.

Yanan, T. ; O. Emteryd ; D.Q. Lu and H. Grip (1997). Effect of organic manure and chemical fertilizer on nitrogen uptake and nitrate leaching in a Eum-orthic anthrosols profile. Nutr. Cycl. Agroecosyst., 48(3): 225229.

\section{تأثير فترة الجفاف قبل الحصاد والتسميا بالبوتاسيوم على النمو والمحصول \\ وجودة العصير لبعض أصناف قصب السكر المبشرة \\ ياسر محمد عبد العزيز \\ معهد بحوث المحاصيل السكرية ، مركز البحوث الزراعية

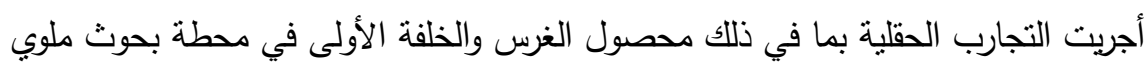

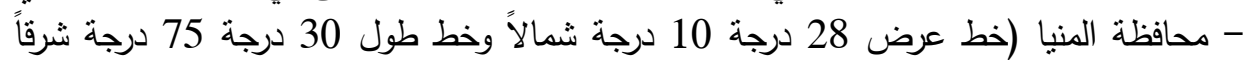

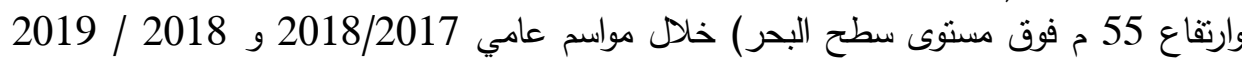

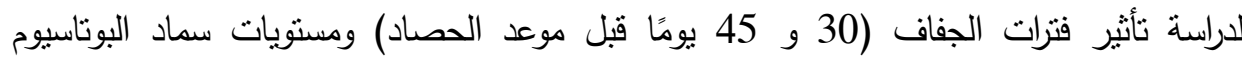

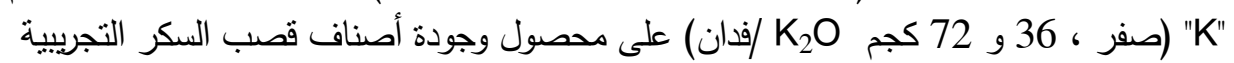

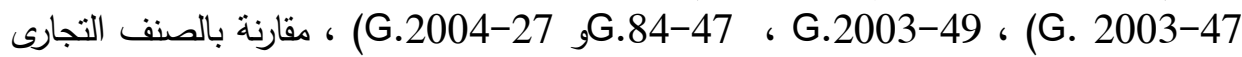
(GT54-9) الجفاف في القطع الرئيسية ، بينما تم توزيع مستويات K في القطعة الثقيقة الأولى ، وتم توزيع

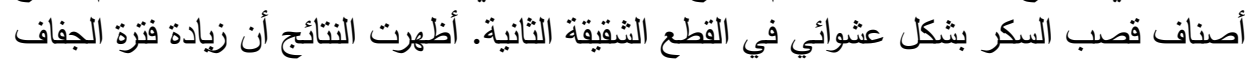

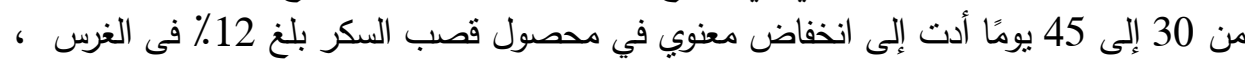

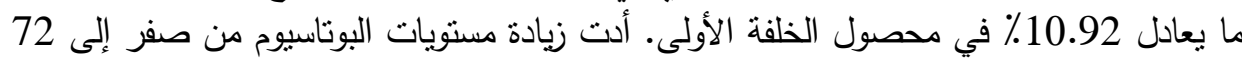

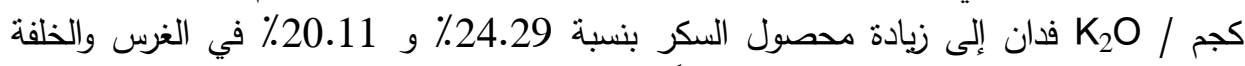

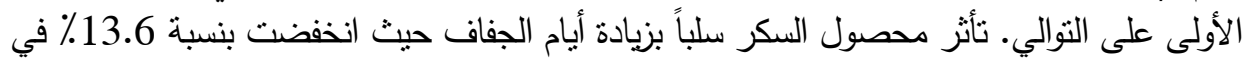

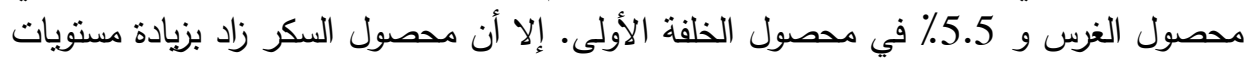

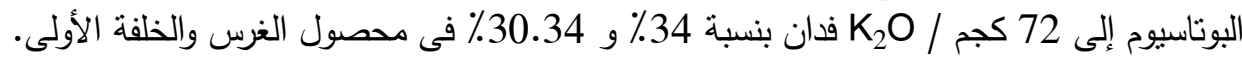

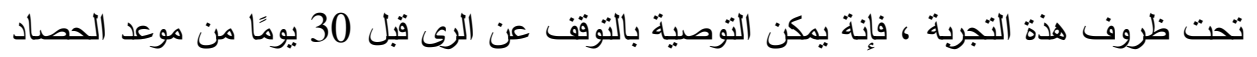

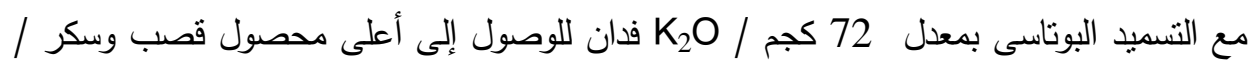

